\title{
Profiling Local Business Enterprises and Direct Effect of Tourism in Villages of Muntei, Madobag and Matotonan, South Siberut, Mentawai, Indonesia
}

\author{
Myrza Rahmanita*, Fetty Asmaniati, Triana Rosalina Dewi \\ Sekolah Tinggi Pariwisata Trisakti \\ *myrzarabmanita@stptrisakti.ac.id
}

\begin{abstract}
Mentawai is well known as an ecotourism area in Indonesia, with its Siberut National Park recognized as part of the World Network of Biosphere Reserves. People come to visit this exotic area every year to do activities and enjoying the natural surroundings, Tourist visits to Mentawai were escalating by years, both domestic and foreign tourists. Regional income from tourism were also increasing. Ecotourism worldwide known for its benefit for economic contribution to local communities and poverty alleviation. The economic contribution of ecotourism is often appreciated through its direct effect on local business enterprises on sites. But then again, statistics today shown that Mentawai are still categorized underdeveloped and poor. Therefore, the objective of this descriptive research was to assess tourism contribution, by means of direct effect to local business enterprises and also challenges faced by villages near Siberut National Park, South Siberut, Mentawai. Survey were conducted in November 2018 by distributing questionnaires to 19 representatives of tourism-related Local Business Enterprises (LBEs) using accidental sampling technique. Data collected were then processed, analyzed and interpreted. In conclusion, this study shows that there is low direct effect of tourism to the existing Local Business Enterprise in the villages of Muntei, Madobag, and Matotonan of South Siberut, Mentawai Island Regency, West Sumatera, Indonesia. In addition, essential
\end{abstract}


Profiling Local Business Enterprises and Direct Effect of Tourism in Villages of Muntei, Madobag and Matotonan, South Siberut, Mentawai, Indonesia

challenges exist, not to mention managerial, predominantly concerning financial and legal matter. It is recommended that local government and other stakeholders put more consideration not only to environmental and social aspects, but also economy, represented by local business enterprises. Initiatives and integrated actions should be arranged and put in practice as to empowering tourism, particularly ecotourism to its optimum, as to bring about foremost contribution to local economy through direct effect of tourism to local business enterprises.

Keywords: Tourism contribution, Direct effect of tourism, Local Business Enterprise, Ecotourism, Mentawai

\section{A. Introduction}

Kabupaten Kepulauan Mentawai, that is Mentawai Islands Regency, termed as Mentawai for short in this study, has long known as exotic ecotourism area located in West Sumatera, Indonesia. Central Bureau of Statistics Indonesia (Badan Pusat Statistik) or BPS for short, shows that tourist visits to Mentawai were 30,048 (2018), 23,825 (2017), 19218 (2016) consisting of foreign tourists 12,325 (2018), 9,833 (2017), 7,982 (2016) and domestic tourists 17,723 (2018), 13,992 (2017), 11.236 (2016) (BPS Mentawai, 2019). According to the Local Government of Mentawai, more than 50 percent of foreign tourists visiting Mentawai in 2017 came from Australia, the United States, Brazil, Japan and Spain (republika.com, 2018). In 2017, Mentawai Islands Regency's regional income from tourism sector reached IDR 7.3 billion. Meanwhile, Land and Building Tax Income from resorts in Mentawai was estimated at IDR 4 billion (republika.com, 2018).

On the other hand, Mentawai still categorized as underdeveloped and poor. Of all 43 villages in Mentawai, 21 are categorized underdeveloped, 19 developing, and only 3 developed villages. (Mentawaikita.com, 2020). Further, there are around 12.99 million people or $14.44 \%$ of poor people in 2018 (BPS Mentawai, 2020).

One of Mentawai tourism potential is Taman Nasional Siberut, or TNS for short, that is Siberut National Park, which long acknowledged as a conservation area and part of the World Network of Biosphere Reserves. Yet limited access to the development activities and utilization of natural resources, resulting in people living around National Parks remained in poverty (Ministry of Forestry, 2011; Santosa, 2004).

Siberut National Park Office plays its role as the conservation area

Tourism Research Journal, Volume 4 (2), 2020 
Profiling Local Business Enterprises and Direct Effect of Tourism in Villages of Muntei, Madobag and Matotonan, South Siberut, Mentawai, Indonesia

management, is promoting ecotourism as one of the missions to save Siberut as proclaimed by the World Wildlife Fund (WWF) in 1980. Ecotourism is a form of sustainable tourism that is expected to encourage conservation and community development, ensuring environmental sustainability and potential economic benefits for local communities. (Chiutsi et al., 2011). Tourism activities in South Siberut, especially near Siberut National Park include walking into the forest, learning about sago and or bark processing, also other activities escalating interest into the philosophy of nature of the Mentawaian (pedoman wisata.com).

According to Litheko and Potgieter (2020), sustainability in the ecotourism sector requires a holistic framework, with the development of a Small Business Enterprise (LBE) at its core. LBE carries out entrepreneurial activities that focus primarily on personal initiatives and skills to create business opportunities in the ecotourism sector while taking into account environmental, cultural values and social goals. The measurement of direct effect is carried out to describe the contribution of tourism to the tourism business sector and to provide a comparison with other industries in other countries and other regions (Driml, 2010).

This study aims to explore tourism contribution to the local economy, reflected through direct effect of tourism to Local Business Enterprises (LBEs). The contribution was assessed by means of direct income received by LBEs, resulted from tourists spending visiting areas in and outside Siberut National Park. Assessments were conducted throughout three villages near Siberut National Park, that is Muntei, Madobag, and Matotonan in South Siberut, the Mentawai Islands Regency, West Sumatera, Indonesia.

The existence of this research is crucial to foresee the potential economic contribution of tourism to the local economy, in terms of its direct effect on LBEs, associated with poverty alleviation, improving village status and input for coaching and empowering LBEs. This study is also useful as a reference for further development of tourism industry in the region and as best practice information regarding direct effects for developing similar tourism industries in other regions. Further, this study could also be beneficial as an alternative reference to further planning and developing villages near Siberut National Park as ecotourism destinations.

\section{B. Literature Review}

\section{Tourism}

Tourism activities are present as one of the largest and fastest growing industries in the world, playing an important role in the economic growth of many countries, benefiting other economic sectors through direct and indirect multiplier effects (Salish and Rodrigues, 2011). Tourism is also recognized as an

Tourism Research Journal, Volume 4 (2), 2020 
Profiling Local Business Enterprises and Direct Effect of Tourism in Villages of Muntei, Madobag and Matotonan, South Siberut, Mentawai, Indonesia

instrument for local economic development and regeneration of rural areas, due to its ability to increase profits and generate economic benefits for regions and local communities (Craggs and Schofield, 2009), to promote development, poverty alleviation, job creation and environmental preservation. (Bezbaruah, 2008). Further, tourism is an important economic activity in most countries around the world. This sector has significant direct and indirect impacts on the economy. (Trebicka, 2016).

Tourism not only creates jobs but also encourages growth in other industrial sectors. Research has shown that the contribution of tourism can be measured through a multiplier effect, namely economic multiplier effect, and the first stage observed is the direct (multiplier) effect of tourism. Determining the multiplier effect of tourism is a very important part of the economy. The multiplier effect measures the expenditure or spending incurred on other parts of the economy, not tourism.

\section{Ecotourism}

The (International) Ecotourism Society (1990) defines ecotourism as responsible travel to natural areas to conserve the environment and improve local communities' welfare. Fennel (2001) describes ecotourism as a form of tourism that can minimize negative impacts, contribute to conservation, provide economic benefits to local communities and opportunities to enjoy natural areas.

The main benefit of ecotourism as reflected in the case study of Chiutsi, et al. (2011), being its potential for providing needed capital for local and national economies without exceeding ecological and cultural carrying capacities. According to Bhattacharya, et al. (2011) ecotourism guarantees the sustainable use of environmental resources, while generating economic opportunities for local communities.

As previously stated, Litheko and Potgieter (2020) suggest that the development of a Small Business Enterprise (LBE) is important for the sustainability in the ecotourism sector. Further, Akbaba (2012) shows that small businesses around the world as important and significant contributors to economic development, job creation, innovation, income generation, and public health and welfare.

The term tourism business includes the transportation business, accommodation business, tour operators, travel agents, tourism promotion and advertising businesses, businesses engaged in tourism insurance and finance, food and beverage business, entertainment business, souvenirs and so on. (Uriely et al., 2002).

There are three types of Small and Medium Business Enterprise in Indonesia, according to Law No. 20 of 2008 article 6 based on net asset ownership and annual sales proceeds, namely Micro Business Enterprise, Small

Tourism Research Journal, Volume 4 (2), 2020 
Profiling Local Business Enterprises and Direct Effect of Tourism in Villages of Muntei, Madobag and Matotonan, South Siberut, Mentawai, Indonesia

Business Enterprise and Medium Business Enterprise. Criteria of Micro Business Enterprise are, (a) Net Assets, not more than IDR 50 million excluding land and buildings for business premises; or (b) Annual sales revenue, not more than IDR 300 million. For Small Business Enterprise, (a) More than IDR 50 million up to a maximum of IDR 500 million excluding land and buildings for business premises; (b) more than IDR 300 million up to a maximum of IDR 2.5 billion. Criteria for Medium Business Enterprise are, (a) Net Assets, more than IDR 500 million up to a maximum of IDR 10 billion excluding land and buildings for business premises; or (b) Annual sales revenue, of more than IDR 2.5 billion up to a maximum of IDR 50 billion.

\section{Multiplier Effect}

The multiplier effect is an effect of impacts that can be presented as an increase in employment in local companies or growth in local government revenues resulted from corporate or personal income tax (Micek, 2011). The multiplier effect was mostly used to determine the economic impact of visitor spending, by multiplying it with the number of tourists and the average spending per visitor (Stynes, 1999).

The multiplier effect reflects the final changes in economic output resulting from initial changes in tourist spending (Ennew, 2003). When new activities begin or the existing develop, a positive multiplier arises through the increase in income and employment. Conversely, if the activity discontinued or its coverage shrank, there will be a decrease in other activities. Therefore, direct effects arising from the commencement of activity in a certain place (job in the company-direct effect) will be accompanied by additional multiplier effects, namely indirect effects and induced effects (Micek, 2011). Direct effect measurement is carried out to report the contribution tourism makes to the tourism sector businesses and compare other industries, countries, and regions (Driml, 2010).

In economic studies, the value of multiplier effects has a relationship with the level of economic development (Yang et al., 2018). The findings of Hansen and Jensen (1996) indicate that a more advanced area can display a higher value multiplier effect. Their research shows that rich regions dominated by 3-star hotels tend to have higher multiplier effects than poor regions dominated by 2 star hotels. Ntibanyurwa (2006) offered evidence of higher multiplier effects on the regions with small businesses.

The concept multiplier effect of tourism can be seen through the perspective of the economic impact of tourism, namely tourist spending on the domestic economy or received by the local community. A study by Menente (Trebicka, 2016) reveals a multiplier effect through the angle of tourist's consumption habits from various origins in terms of compositions and

Tourism Research Journal, Volume 4 (2), 2020 
Profiling Local Business Enterprises and Direct Effect of Tourism in Villages of Muntei, Madobag and Matotonan, South Siberut, Mentawai, Indonesia

expenditure levels. Multipliers in tourism are often divided into five types (ProPoor Tourism Partnership, 2004; Ennew, 2003), namely income multiplier, employment multiplier, sales/transaction multiplier, government revenue multiplier, and output multiplier. (Ntibanyurwa, 2008).

Tourism multipliers on income and employment generation can be observed at three different levels (Carstensen, 2003; Pao, 2005). Firstly, the direct effects of tourism are known as the primary effect. The direct effect occurs when tourist spending goes straight into the tourist industry. In this case, tourism creates income and employment directly into sectors connected to it to supply tourist goods and services. Secondly, the indirect effect of tourism, sectors that supply directly to the tourism industry, use the income they have received from tourism to buy their inputs from other industries in order to produce and satisfy the demand from the tourism industry. One model of indirect impact is the expenditure of the manager to pay labor wages. It is called indirect because industries in this category do not deal directly with the tourism sector or the tourist consumer itself. Thirdly, induced effects (effects that are induced or further effects) are the economic activity changes in tourist sites from the labor spending to meet their needs. Or in this case, the income from the tourism sector used to purchase other than tourism-related goods and services create induced effects. Both indirect and induced effects are also known as secondary effects of tourism (Ennew, 2003; Sugiyarto et al.., 2003).

The community in a tourism village plays an important role in developing a tourist village as a supporting industry for the tourism sector which is developed as a characteristic of tourist attractions which are one of these tourist destinations. Village communities can make various products related to tourism. This sector will survive if the number of tourist visits can continue to increase and tourists will buy these products (Suprina and Nathania, 2018). The development of a tourism village has a positive impact on economic, social and environmental aspects for the village community as a local community, so that the development of a tourist village is welcomed by the surrounding community (Festivalia et al., 2019).

\section{Research Methodology}

Within this research, measuring the economic contribution of tourism was conducted by assessing the direct effect of tourism to the local economy, that is to local business enterprises. The methodology used in this tourism direct effect research is descriptive method with a quantitative approach. Data and information were collected by way of survey through questionnaires distribution, observation, as well as material documentation. Nineteen LBEs providing tourism goods and services in the villages of Muntei, Madobag, and Matotonan, near Siberut National Park, Mentawai were chosen as sample respondents using

Tourism Research Journal, Volume 4 (2), 2020 
Profiling Local Business Enterprises and Direct Effect of Tourism

in Villages of Muntei, Madobag and Matotonan, South Siberut, Mentawai, Indonesia

non probability accidental random sampling. Those nineteen LBEs are representatives from the national park; restaurant, stalls and local eatery, travel and tour agent; hotel, resort, guest house, homestay, and local inn; land, water and air transportation; souvenir and gift shop; as well as several types of local and traditional stores, selling office supplies and photocopy services; animal food; raw food; also clothing, fashion and watches.

Survey on the LBEs was conducted in November 2018, assessing the direct effect impacted from tourism activities, in terms of Characteristics of LBEs sample respondents; Characteristics of LBEs; and Contribution of tourism to LBEs.

\section{Result and Discussion}

Tourism activities in South Siberut, particularly near Siberut National Park have its economic impacts on surrounding communities. Tourists spend some amounts of money to meet their needs and wants. These spendings are received by the business enterprise. Yet the survey results showed that nearly forty percent of respondents do not have data on tourist visit to Siberut National Park for the last 5 years nor the latest. This is due to the location of business enterprises which are not adjacent to the location of National Park. A respondent mentioned that the number of tourist visits was around 18 per month. This number decreases and increases due to the nature of high/low season (seasonality factor). The number of tourist arrival at Siberut National Park has also decreased due to the shift in tourists' interest. They are recently more interested in surfing rather than nature or culture attractions. The statistics on National Park visitor data were gained from the guest book, also estimation report and information from Siberut National Park team on sites.

\section{Characteristics of Local Business Enterprise Sample Respondents}

Characteristics of Local Business Enterprises (LBEs) sample respondents are grouped by gender, age, education, occupation, and income categories. The majority of LBEs were directly involved in trading activities without hiring workers. Gender-based, there are $63.2 \%$ businessmen compared to $36.8 \%$ women (table 1). This finding is in line with the result study of Akbaba, A. (2012) revealing the high proportion of male small tourism businesses' owners compared to female. By age category (table 2), 42.1\% of respondents are $25-40$ years of age, followed by $18-25$ years of age at $26.3 \%$, while the oldest is 70 years. Concerning education level, most respondents of $63.2 \%$. are vocational/regular high school graduates. Based on occupation, most respondents of $63.2 \%$ are business owner. Whereas by income level as shown in (table 3), the largest, at around $47.4 \%$ is its income exceeding IDR 1 million to IDR 2 million. Most respondents are Mentawai Island Regency residents, and

Tourism Research Journal, Volume 4 (2), 2020 
Profiling Local Business Enterprises and Direct Effect of Tourism in Villages of Muntei, Madobag and Matotonan, South Siberut, Mentawai, Indonesia

only one comes from Padang City; all of them live in South Siberut, Mentawai. Most traders are natives, yet one third (almost 37 percent) are migrants who come from outer Mentawai.

Table 1. Gender

\begin{tabular}{clcccc}
\hline & Frequency & Percent & $\begin{array}{l}\text { Valid } \\
\text { Percent }\end{array}$ & $\begin{array}{l}\text { Cumulative } \\
\text { Percent }\end{array}$ \\
\hline \multirow{3}{*}{ Valid } & Male & 12 & 63.2 & 63.2 & 63.2 \\
& Female & 7 & 36.8 & 36.8 & 100.0 \\
& Total & 19 & 100.0 & 100.0 & \\
\hline
\end{tabular}

Source: raw data processed

Table 2. Age

\begin{tabular}{cccccc}
\hline & Frequency & Percent & $\begin{array}{c}\text { Valid } \\
\text { Percent }\end{array}$ & $\begin{array}{c}\text { Cumulative } \\
\text { Percent }\end{array}$ \\
\hline \multirow{4}{*}{ Valid } & 18 - 25 Years old & 5 & 26.3 & 26.3 & 26.3 \\
& $>$ 25 - 40 Years old & 8 & 42.1 & 42.1 & 68.4 \\
& $>$ 40 - 55 Years old & 4 & 21.1 & 21.1 & 89.5 \\
& $>55-70$ Years old & 2 & 10.5 & 10.5 & 100.0 \\
& Total & 19 & 100.0 & 100.0 & \\
\hline
\end{tabular}

Source: raw data processed

Table 3. Monthly Income

\begin{tabular}{llcccc}
\hline & Frequency & Percent & $\begin{array}{c}\text { Valid } \\
\text { Percent }\end{array}$ & $\begin{array}{c}\text { Cumulative } \\
\text { Percent }\end{array}$ \\
\hline Valid & < IDR 1 million & 5 & 26.3 & 26.3 & 26.3 \\
& 1 - 2 million & 10 & 52.6 & 52.6 & 78.9 \\
& $>$ 2 - 3 million & 1 & 5.2 & 5.2 & 84.2 \\
& $>$ 3 - 4 million & 1 & 5.2 & 5.2 & 89.5 \\
& $>$ 4 - 5 million & 1 & 5.2 & 5.2 & 94.7 \\
& $>$ 5 million & 1 & 5.2 & 5.2 & 100.0 \\
Total & 19 & 100.0 & 100.0 & \\
\hline
\end{tabular}

Source: raw data processed

\section{Characteristics of Local Business Enterprises}

Local Business Enterprises' characteristics are grouped by Types of Business, Capital Ownership or Institutional Form, Business Distance from the National Park, Transportation Mode, Locality composition and origin of goods, services and labors provided.

The nineteen Local Business Enterprises (LBEs) categorized by Business Types, are National Park; Accommodation (21.1\%); Restaurants and eateries (36.8\%); Souvenir and gift shops (31.6\%) also tour, travel and transportation

Tourism Research Journal, Volume 4 (2), 2020 
Profiling Local Business Enterprises and Direct Effect of Tourism in Villages of Muntei, Madobag and Matotonan, South Siberut, Mentawai, Indonesia

$(10.5 \%)$.

Most respondents (90 percent) indicate that business unit capital ownership belongs to local private companies with the institutional form of the Individuals LBE without legal entities. The next ten percent is State-Owned Enterprise (SEO) and or Municipally-Owned Corporations (MOC), with the local government as the owner of the capital.

$89.5 \%$ of the existing LBE is located more than 10 kilometers to the National Park, and another 10.5\% located between 5.1 to 10 kilometers (table 4). Implicitly, this indicates that most LBEs are not too dependent on forest products or production in National Park. Even so, they are still expecting tourists to come and visit Siberut National Park, which has the potential to provide economic benefits for the community and the region; especially if it is well managed, directed and integrated.

Table 4. Distance from Local Business Enterprise to Siberut National Park

\begin{tabular}{cccccc}
\hline & Frequency & Percent & $\begin{array}{c}\text { Valid } \\
\text { Percent }\end{array}$ & $\begin{array}{c}\text { Cumulative } \\
\text { Percent }\end{array}$ \\
\hline \multirow{3}{*}{ Valid } & $>5-10$ kilometers & 2 & 10.5 & 10.5 & 10.5 \\
& $>10$ kilometers & 17 & 89.5 & 89.5 & 100.0 \\
& Total & 19 & 100.0 & 100.0 & \\
\hline
\end{tabular}

Source: raw data processed

Due to its natural environments, there are two transportation modes available for the trip from LBEs to Siberut National Park, 63.2\% using water, and $26.3 \%$ land transportation mode (table 5). The inadequate access to transportation mode has resulted in people having to rent canoes if they want to sell their crops or production businesses.

Table 5. Transportation Mode

\begin{tabular}{lccccc}
\hline & Frequency & Percent & Valid Percent & $\begin{array}{c}\text { Cumulative } \\
\text { Percent }\end{array}$ \\
\hline Valid & & & & 10.5 \\
& Water & 12 & 10.5 & 10.5 & 73.7 \\
& Land & 5 & 26.2 & 63.2 & 100.0 \\
& Total & 19 & 100.0 & 100.0 & \\
\hline
\end{tabular}

Source: raw data processed

Refer to its locality, currently almost all LBEs maintain to use a hundred percent local components, whether of its goods, services and labor. In carrying out its operations, eighty percent of LBEs within the area of Siberut National Park are generally affiliating with private sector partners (including suppliers), in

Tourism Research Journal, Volume 4 (2), 2020 
Profiling Local Business Enterprises and Direct Effect of Tourism in Villages of Muntei, Madobag and Matotonan, South Siberut, Mentawai, Indonesia

addition to local governments and others.

\section{Contribution of Tourism to Local Business Enterprises}

The total annual income of LBEs in Siberut National Park ranged from IDR 10 million to IDR 30 million (table 6), that is around IDR 800 thousand to IDR 2.5 million per month. This supports the previous assumption that even though LBE still operates in a daily manner, it is not yet profitable enough for LBEs to become significant contributors to the region's economy. Only a few LBEs stated that they received donations or assistance from the community. Within the area of Siberut National Park, only one LBE mentioned receiving assistance of IDR 200 thousand per month, which is not enough to escalate their business operations. Based on their total annual income, which below IDR 300 million, all LBEs are classified as Microbusiness enterprises.

Table 6. Business Annual Income

\begin{tabular}{llcccc}
\hline & $\begin{array}{c}\text { Frequenc } \\
\mathrm{y}\end{array}$ & $\begin{array}{c}\text { Percen } \\
\mathrm{t}\end{array}$ & $\begin{array}{c}\text { Valid } \\
\text { Percent }\end{array}$ & $\begin{array}{c}\text { Cumulative } \\
\text { Percent }\end{array}$ \\
\hline \multirow{6}{*}{ Valid } & < IDR 10 million & 14 & 73.7 & 73.7 & 73.7 \\
& IDR 10 million & 1 & 5.3 & 5.3 & 78.9 \\
& IDR 15 million & 1 & 5.3 & 5.3 & 84.2 \\
& IDR 20 million & 1 & 5.3 & 5.3 & 89.5 \\
& IDR 25 million & 1 & 5.3 & 5.3 & 94.7 \\
& IDR 30 million & 1 & 5.3 & 5.3 & 100.0 \\
\hline
\end{tabular}

Source: raw data processed

The annual operational costs of LBEs in Siberut National Park ranged from IDR 5 million to IDR 50 million (table 7), or around IDR 420 to 4.170 thousand per month, including permanent employee salaries, which generally range from IDR 750 thousand to IDR 20 million (table 8); Part-time employee salaries, around IDR 500 thousand to IDR 800 thousand (table 9); Utility expenses from IDR 250 thousand to IDR 13 million (table 10); Transportation expenses are around IDR 250 thousand to IDR 1 million (table 11); Maintenance expenses in average are IDR 1 million; while Expenditures for Shopping Material range from IDR 500 thousand - IDR 1 million. 
Profiling Local Business Enterprises and Direct Effect of Tourism in Villages of Muntei, Madobag and Matotonan, South Siberut, Mentawai, Indonesia

Table 7. Annual Operational Cost

\begin{tabular}{llcccc}
\hline & Frequency & Percent & $\begin{array}{c}\text { Valid } \\
\text { Percent }\end{array}$ & $\begin{array}{c}\text { Cumulative } \\
\text { Percent }\end{array}$ \\
\hline \multirow{6}{*}{ Valid } & < IDR 5 million & 14 & 73.7 & 73.7 & 73.7 \\
& IDR 5 - 10 million & 2 & 10.5 & 10.5 & 84.1 \\
& IDR 10 - 15 million & 1 & 5.3 & 5.3 & 89.4 \\
& IDR 15 - 50 million & 1 & 5.3 & 5.3 & 94.7 \\
& > IDR 50 million & 1 & 5.3 & 5.3 & 100.0 \\
& Total & 19 & 100.0 & 100.0 & \\
\hline
\end{tabular}

Source: raw data processed

A number of LBEs in Siberut National Park were indicated to have Manager-level employees with salaries ranging from IDR 1.5 million to IDR 2 million. Salaries for sales employees are around IDR 0.5 million for part-time workers up to IDR 1.5 million for permanent staff.

Table 8. Permanent Employee Salaries

\begin{tabular}{llcccc}
\hline & $\begin{array}{c}\text { Frequenc } \\
\mathrm{y}\end{array}$ & Percent & $\begin{array}{c}\text { Valid } \\
\text { Percent }\end{array}$ & $\begin{array}{c}\text { Cumulative } \\
\text { Percent }\end{array}$ \\
\hline \multirow{6}{*}{ Valid } & < IDR 750 thousand & 14 & 73.7 & 73.7 & 73.7 \\
& IDR 750 thousand & 2 & 10.5 & 10.5 & 84.2 \\
& IDR 1 million & 1 & 5.3 & 5.3 & 89.5 \\
& IDR 1.5 million & 1 & 5.3 & 5.3 & 94.7 \\
& IDR 20 million & 1 & 5.3 & 5.3 & 100.0 \\
& Total & 19 & 100.0 & 100.0 & \\
\hline
\end{tabular}

Source: raw data processed

Table 9. Part-time Employee Salaries

\begin{tabular}{llcccc}
\hline & Frequency & Percent & Valid Percent & $\begin{array}{c}\text { Cumulative } \\
\text { Percent }\end{array}$ \\
\hline \multirow{4}{*}{ Valid } & & & & 89.5 & 89.5 \\
& < IDR 500 thousand & 17 & 89.5 & 5.3 & 94.7 \\
& IDR 500 thousand & 1 & 5.3 & 5.3 & 100.0 \\
& IDR 800 thousand & 1 & 5.3 & 100.0 & \\
\hline & Total & 19 & 100.0 & 100 \\
\hline
\end{tabular}

Source: raw data processed

Tourism Research Journal, Volume 4 (2), 2020 
Profiling Local Business Enterprises and Direct Effect of Tourism in Villages of Muntei, Madobag and Matotonan, South Siberut, Mentawai, Indonesia

Table 10. Utility Expenses

\begin{tabular}{llcccc}
\hline & $\begin{array}{c}\text { Frequenc } \\
\mathrm{y}\end{array}$ & $\begin{array}{c}\text { Percen } \\
\mathrm{t}\end{array}$ & $\begin{array}{c}\text { Valid } \\
\text { Percent }\end{array}$ & $\begin{array}{c}\text { Cumulative } \\
\text { Percent }\end{array}$ \\
\hline \multirow{6}{*}{ Valid } & < IDR 150 thousand & 13 & 68.4 & 68.4 & 68.4 \\
& IDR 150 thousand & 1 & 5.3 & 5.3 & 73.7 \\
& IDR 200 thousand & 3 & 15.8 & 5.3 & 89.5 \\
& IDR 250 thousand & 1 & 5.3 & 5.3 & 94.7 \\
& IDR 13 million & 1 & 5.3 & 5.3 & 100.0 \\
Total & 19 & 100.0 & 100.0 & \\
\hline
\end{tabular}

Source: raw data processed

Table 11. Transportation Cost

\begin{tabular}{llcccc}
\hline & Frequency & Percent & $\begin{array}{c}\text { Valid } \\
\text { Percent }\end{array}$ & $\begin{array}{c}\text { Cumulative } \\
\text { Percent }\end{array}$ \\
\hline \multirow{6}{*}{ Valid } & & & 73.7 & 73.7 & 73.7 \\
& < IDR 250 Thousand & 14 & 5.3 & 5.3 & 79.0 \\
& IDR 250 Thousand & 1 & 10.5 & 10.5 & 89.5 \\
& IDR 800 Thousand & 2 & 10.5 & 10.5 & 100.0 \\
& IDR 1 million & 2 & 100.0 & 100.0 & \\
\hline & Total & 19 & & &
\end{tabular}

Source: raw data processed

Total Capital Outlay (TCO), that is expenditures outside LBEs' operational cost, which generally less or the same as IDR 100 million. LBEs expect their upcoming TCO to be like the previous TCO, which is less than or the same as IDR 100 million; indicates risk averse. It is indicated that expenditures for promotion have not been fully prepared, for example expenses for festivals or events; expenses for promotion; expenditures for media advertising printing; as well as electronic media advertising.

By having no respondents responding about tax expenditures and regional contributions, it is assumed that LBEs hardly contribute in both forms. This is a poor indication, which implies two things. Firstly, LBEs have not been able to carry out its operations in such a way to a level that allows them to pay taxes. Secondly, by having insufficient profit, it is suspected that LBEs have not contributed as much as they should. These implications were attributed to the condition that $94.7 \%$ of the LBEs owned by individuals without legal entities. These arguments were constructed through respondents' responses given during an unpretentious interview. 
Profiling Local Business Enterprises and Direct Effect of Tourism in Villages of Muntei, Madobag and Matotonan, South Siberut, Mentawai, Indonesia

\section{E. Conclusion and Recommendations}

This study concludes that tourism contributes in terms of direct effect to local business enterprises near Siberut National Park, in South Siberut, Mentawai. Yet the contribution has not yet optimal, shown by all those tourismrelated local enterprises were all micro categorized, none of them small, nor medium business enterprises. Nevertheless, challenges are faced, not to mention insufficient funds for promotion. The majority of local business enterprises were owned by individuals without legal entities that bring about small tax payment and low regional contribution.

Recommendations were given by this research. Firstly, tourism development should sustainably continue, by means of ecotourism, to increase the income of local business enterprises near Siberut National Park, in the area of South Siberut, Mentawai. Secondly, the government should help to facilitate local business enterprises, in terms of promotion, and also fostering the arrangement of institutional legal form. The benefit of this institutional legal will facilitate development and financial assistance or loans that require institutional formalities.

It is recommended that local government and other stakeholders put more consideration not only on environmental and social aspects, but also the economy, represented by local business enterprises. Initiatives and integrated actions should be arranged and put in practice to empower tourism, particularly ecotourism, to its optimum, as to bring about a foremost contribution to the local economy through the direct effect of tourism to local business enterprises.

The limitation of this research is particularly related to time and space. In other words, with a very limited time, the researcher also faced difficulty in accessing the three villages in those remote areas of Mentawai, using only a small canoe as the only transportation mode available at that time being. For future research, it is recommended to spare more time to come to sites to have a thorough and more holistic study.

\section{F. Acknowledgment}

The researchers would like to acknowledge with gratitude the supports given by Tropical Forest Conservation Action (TFCA), who have made this research possible to be conducted.

\section{REFERENCES}

Akbaba, A. (2012) Understanding Small Tourism Businesses: A Perspective from Turkey. Journal of Hospitality and Tourism Management, 19, page 1 of 17, e9.

Tourism Research Journal, Volume 4 (2), 2020 
Profiling Local Business Enterprises and Direct Effect of Tourism in Villages of Muntei, Madobag and Matotonan, South Siberut, Mentawai, Indonesia

Bezbaruah, M.P. (2008). Development Trends and The Role of Tourism in Northeastlndia. ASCI Journal of Management, 37 (2), 122-123.

Bhattacharya, D., Chowdhury, B., \& Sarkar, R. (2011). Irresponsible Ecotourism Practices Flanking the Best National Park in India: A Multwariate Analysis. 2nd International Conference on Business and Economic Research (2nd Icber 2011) Proceeding, 1901-1928.

BPS Mentawai. (2019). Kabupaten Kepulauan Mentawai Dalam Angka 2019. Mentawaikab.bps.go.id.

BPS Mentawai. (2020). Kabupaten Kepulauan Mentawai Dalam Angka 2019. Mentawaikab.bps.go.id.

Carstensen, F.V. (2003). The 2001 Economic Impact of Connecticut's Travel and Tourism Industry. Connecticut Center for Economic Analysis, University of Connecticut.

Chiutsi, S., Mukoroverwa, M., Karigambe, P \& Mudzeng, B.K. (2011) The theory and practice of ecotourism in Southern Africa. Journal of Hospitality Management and Tourism, 2(2), 14-21

Craggs, R. \& Schofield, P. (2009). Expenditure-based segmentation and visitor profiling at The Quays in Salford, UK. Tourism Economics, 15(1), 243-260.

Driml, S. (2010). Handbook on measuring the economic value of tourism to national parks. CRC for Sustainable Tourism Pty Ltd. CRC.

Ennew, C. (2003). Understanding the Economic Impact of Tourism. Discussion Paper 2003/05, Tourism and Travel Research Institute.

Fennel DA (2001). A content analysis of ecotourism definitions. Curr. Iss. Tourism, 4(5), 403-421.

Festivalia, F., Enggriani, M., \& Pramanik, P. D. (2019). The Impact of Tourism on Village Society. TRJ (Tourism Research Journal), 3(2), 178-187.

Hansen, C., \& Jensen, S. (1996). The Impact of Tourism on Employment in Denmark: Different Definitions, Different Results. Tourism Economics, 2(4),.283-302.

Litheko, A., \& Potgieter, M. (2020) Development and Management of Ecotourism Small Business Enterprises: North West Province, South Africa. International Journal of Conceptions on Management and Social Sciences 6(1).

Micek, G. (2011). Estimating multiplier effects on the local scale. Acta Universitat Islodziensis, Folia Oeconomica 252, 176.

Ministry of Forestry (2011). Peraturan Menteri Kebutanan Republik Indonesia Nomor: P. 16/Menbut-II/ 2011 tentang Pedoman Umum Program Nasional Pemberdayaan Masyarakat Mandiri Kehutanan. Number: P. 16 / Min.Forest-II / 2011 concerning General Guidelines for the National Forestry Independent Community Empowerment Program.) Jakarta: Ministry of Forrstry.

Mentawaikita.com (2020) 21 Desa di Mentawai Masih Kategori Tertinggal.

Tourism Research Journal, Volume 4 (2), 2020 
Profiling Local Business Enterprises and Direct Effect of Tourism in Villages of Muntei, Madobag and Matotonan, South Siberut, Mentawai, Indonesia

https://www.mentawaikita.com/baca/3932/21-desa-di-mentawaimasih-kategori-tertinggal.

Ntibanyurwa, A. (2008). The income and employment multiplier effects of tourism: The Case of Rwanda. Thesis of Doctor of Philosophy in the Department of Economics, University of the Western Cape 72.

Pao, J. W. (2005). A review of economic impact analysis for tourism and its implication for Macao. Monetary Authority of Macao, Macao.

Pedoman wisata.com https://www.pedomanwisata.com/wisata-sejarah/desatradisional/pulau-siberut-petualangan-menjelajahi-hutan-dan-pantai-yangmasih-asli-di-mentawai.

Pro-Poor Tourism Partnership. (2004). Sheet No. 9: Tourism in Poverty Reduction. Strategy Papers (PRSPs). http://www.propoortourism.org.uk.

Republika.co.id (2018). https://www.republika.co.id/berita/nasional/daerah/ 18/03/18/p5slc7428-pendapatan-mentawai-dari-pariwisata-capai-rp-73miliar.

Salish, N., \& Rodrigues, P.M.M. (2011). Panel Seasonal Unit Root Tests: An Application to Tourism. Berlin Heidelberg: Springer- Verlag.

Santosa I. (2004). Pemberdayaan Petani Tepian Hutan Melalui Pembaharuan Perilaku Adapatif (Empowerment of Forest Farmers through Adaptive Behavior Renewal). Dissertation, Sekolah Pascasarjana, Institut Pertanian Bogor.

Stynes, D. J. (1999). Approaches to Estimating the Economic Impacts of Tourism: Some Examples. Economic Impact Approaches. East Lansing: MI.

Sugiyarto, G., Blake, A., \& Sinclair, M.T. (2003). Tourism and globalization: economic impact in Indonesia. Annals of Tourism Research, 30 (3), 683-701.

Suprina, R., \& Nathania, A. A. (2018). How To Develop Kampung Wisata Batik Pesindon As A Tourist Destination In Pekalongan Through SWOT Analysis. TRJ (Tourism Research Journal), 2(1), 14-27.

TFCA (Trisakti School of Tourism and Tropical Forest Conservation Action for Sumatera). (2018). Study of Ecotourism Potential in 7 (Seven) National Parks in Sumatra. TST \& TFCA, 78-79.

The International Ecotourism Society (TIES). (2015). TIES Announces Ecotourism Principles Revision. https://ecotourism.org/news/tiesannounces-ecotourism-principles-revision/.

Trebicka, B. (2016). Torism as a Multiplier Effect in Economy: The Case of Albania. International Journal of Business and Management Invention, $5(1), 17-21$.

Uriely, N., Yonay, Y., \& Simchai, D. (2002). Backpacking and tourist experience: A type and form analysis. Annals of Tourism Research, 10(1), 87-107.

Yang, Y., Fik, T. J. \& Altschuler, B., (2018). Explaining regional economic multipliers of tourism: does cross-regional heterogeneity exist?. Asia Pacific Journal of Tourism Research, 23(1),15-23.

Tourism Research Journal, Volume 4 (2), 2020 